\title{
High metal contents found in Fulico septica (L.) Wiggers and some other slime molds (Myxomycetes)
}

\author{
ANNAMAIJA SETÄLÄ and PEKKA NUORTEVA
}

\begin{abstract}
SETÄLÄ, A. \& NUORTEVA, P. 1989: High metal contents found in Fulico septica (L.) Wiggers and some other slime molds (Myxomycetes). - Karstenia 29:37-44.

The metal contents of Fulico septica, seven other slime molds and two unidentified slime mold plasmodia were studied and compared with the levels in Vaccinium myrtillus leaves collected at the same time from the same place. The levels of $\mathrm{Cd}, \mathrm{Cu}$ and especially $\mathrm{Zn}$ were generally far higher in the slime molds. The levels of $\mathrm{Zn}$ in Fulico septi$c a$ were so high (4000-20 000 ppm) that it is difficult to understand how a living organism can tolerate them. The levels of $\mathrm{Al}$ and $\mathrm{Fe}$, on the other hand, were higher in $V$. myrtillus. This research underlines the importance of humus as a source of metals for the organisms living in it. It also shows simultaneous peak occurrence of the useful micronutrients $\mathrm{Cu}$ and $\mathrm{Zn}$ and the toxic $\mathrm{Cd}$, to which the former seems to be antagonistic. The main value of this material is that it provides information for future work.
\end{abstract}

Key words: Al, Cd, $\mathrm{Cu}, \mathrm{Fe}$, Fuligo septica, $\mathrm{Hg}$, myxomycetes, slime mold, $\mathrm{Zn}$

Annamaija Setälä \& Pekka Nuorteva, Department of Environmental Conservation, University of Helsinki, SF-00710 Helsinki, Finland

\section{Introduction}

Slime molds (Myxomycetes) have commonly been neglected in studies on forest ecology and also in investigations of the role of toxic metals in the multistress disease killing forests in Europe. They are of great potential interest, however, because several kinds of saprophags in the forest ecosystem accumulate metals very vigorously (Andersen 1978, Beyer et al. 1982, Beyer et al. 1985, Pokarzhevskij et al. 1978, Pokarzhevskij et al. 1982). Some changes in the amounts and physiology of soil organisms have also been observed (Bengtson \& Rundgren 1984, Beyer \& Anderson 1985, Tyler \& Westman 1979).

In their natural habitats, the plasmodia of slime molds obtain nutrients by ingesting solid food particles, including bacteria, fungi, and in some cases also algae and other substrates as well (Gray \& Alexopoulos 1968). To some degree at least, the metal contents of Myxomycetes can be expected to reflect the metal levels of their food.

Some laboratory experiments have been performed to determine the toxicity of heavy metals to the slime mold Physarum polycephalum. These have shown that high contents of heavy metals affect the membrane potential, nuclear biochemistry and survival time of this slime mold (Chin et al. 1973, Chin et al. 1978a, 1987b, Chin \& Sina 1978, Terayama et al. 1978).

Preliminary determinations made in our laboratory of the metal contents in some dried museum specimens of Lycogala epidendrum (L.) and Fuligo septi$c a$ from the Botanical Museum of Helsinki University showed extremely high $\mathrm{Zn}$ levels in $F$. septica, and high metal contents in general (Table 1). It was therefore decided to study the metal levels in material collected from nature.

The metals chosen for study were $\mathrm{Al}, \mathrm{Fe}, \mathrm{Zn}, \mathrm{Cu}$, $\mathrm{Cd}$ and $\mathrm{Hg}$, i.e. two common soil metals, two useful plant micronutrients and two poisonous metals. The metal levels in leaves of Vaccinium myrtillus were studied in order to have a measure of the general metal load of each locality. V. myrtillus has earlier been used successfully by our laboratory as an indicator of this kind (Särkelä \& Nuorteva 1987, Kanerva et al. 1988, Koski et al. 1988). 
Table 1. Metal levels in specimens of Fuligo septica and Lycogala epidendrum in the Botanical Museum of the University of Helsinki. The levels are given as $\mathrm{mg} / \mathrm{kg} \mathrm{dwt}=\mathrm{ppm}$ of air-dry weight. The values are for individual slime molds.

\begin{tabular}{|c|c|c|c|c|c|c|}
\hline & & $\mathrm{Al}$ & $\mathrm{Fe}$ & $\mathrm{Zn}$ & $\mathrm{Cu}$ & $\mathrm{Cd}$ \\
\hline \multicolumn{7}{|c|}{ Fuligo septica } \\
\hline Merimasku & 1860 & 40 & 27 & 11000 & 13 & 2.1 \\
\hline Lohja & 16.10 .1909 & 26 & 32 & 5100 & 12 & 1.3 \\
\hline Tenhola & 23.4.1935 & 64 & 57 & 3600 & 12 & 1.6 \\
\hline Kankaanpää & 28.8 .1935 & 3.4 & 22 & 2200 & 9.6 & 2.7 \\
\hline Västanfjärd & 6.8 .1959 & 21 & 92 & 2600 & 11 & 3.2 \\
\hline \multicolumn{7}{|c|}{ Lycogala epidendrum } \\
\hline Porvoo & 9.9 .1870 & 35 & 38 & 35 & 5.7 & 0.28 \\
\hline Espoo & 4.10 .1909 & 190 & 200 & 49 & 3.8 & 0.28 \\
\hline Helsinki & 15.4 .1938 & 47 & 55 & 69 & 3.4 & 1.1 \\
\hline Porvoo & 1.5.1964 & 490 & 580 & 82 & 4.6 & 0.57 \\
\hline
\end{tabular}

\section{Material}

The material was collected from different habitats, mainly a forest near the small town Kokemäki, in southwestern Finland. The study area is about $0.1 \times$ $5 \mathrm{~km}$. The main tree in that area is Pinus sylvestris, $V$. myrtillus being a common undershrub. The forest lies approximately $25 \mathrm{~km}$ south-east of Harjavalta, an industrial town, known to be a major contributor to metal pollution in the area (Laaksovirta \& Silvola 1975, Hynninen 1986, Hynninen \& Lodenius 1986, Arstila et al. 1986, Kuokkanen 1986, Sippola \& Erviö 1986, Heliövaara et al. 1987). According to the previous investigations, however, the metal pollution does not reach the present study area to any great extent.

The sampling locality in Köyliö was a clear-cut pine forest, in Nummi-Pusula it was a birch forest near the Helsinki-Pori road. The localities in Espoo, Vantaa and Juupajoki were all spruce forests, but in Juupajoki some of the samples were collected from a swamp. The Pyhäranta sampling area was in the yard of a summer cottage located in pine forest near the seashore.

The samples were collected between 5.7.1988 and 22.9.1988.

\section{Methods}

The slime molds and the blueberry leaves were collected by hand and placed in plastic containers $(100 \mathrm{ccm})$. Most of the slime mold samples consisted of mature, individual aethalia, a few of plasmodia. The latter were frozen immediately. In the laboratory the samples were dried at room temperature for about a week before the containers were closed. To prevent metal fallout on the samples during this phase they were protected with a sheet of paper. Metal tools were not used during collection or handling of the samples.

Final drying was performed at $40^{\circ} \mathrm{C}$ for 24 hours. The samples collected as plasmodia, however, and first treated by freezing - were dried for 3 days in $40^{\circ} \mathrm{C}$.

Samples weighing more than $0.6 \mathrm{~g}$ were divided into two, one part being analysed for $\mathrm{Hg}$ and the other for the other metals. $\mathrm{Hg}$ was not determined on small samples. The larger Fulico septica samples were also divided into two: the hypothallus and the sporophore. The hypothallus was of course contaminated to some degree by the spores.

For the analyses the samples were digested in $5 \mathrm{ml}$ of $65 \% \mathrm{HNO}_{3}$ (Merck, Suprapur) for $2 \mathrm{~h}$ at $50^{\circ} \mathrm{C}$, for $4 \mathrm{~h}$ at $110^{\circ} \mathrm{C}$ and for $4 \mathrm{~h}$ at $170^{\circ} \mathrm{C}$. The samples analysed for $\mathrm{Hg}$ were digested in $5 \mathrm{ml}$ $\mathrm{HNO}_{3}-\mathrm{H}_{2} \mathrm{SO}_{4}$ mixture $(1: 4)$ at $85^{\circ} \mathrm{C}$ for $4 \mathrm{~h}$. All the samples were filtered and diluted to $25 \mathrm{ml}$ with distilled water. The samples were analysed for $\mathrm{Cu}, \mathrm{Fe}$ and $\mathrm{Zn}$ with a Varian spectr AA-40 flame Atomic Absorption Spectrophotometer; for $\mathrm{Cd}$ and in the case of the smallest samples Graphite Furnace was used; The $\mathrm{Al}$ analyses were done with a Perkin-Elmer 360 flame AAS and the $\mathrm{Hg}$ analyses with a Perkin-Elmer MAS-50. 
Table 2. Metals in Fuligo septica (L.) Wiggers growing on different substrates in the Satakunta (Køyliö and Kokemäki) and Uusimaa (Espoo and Nurmijärvi) provinces. The background levels of metals in the sampling localities are represented by the metal contents in the leaves of Vaccinium myrtillus $\mathrm{L}$. The metal levels are given as $\mathrm{mg} / \mathrm{kg} \mathrm{dwt}=\mathrm{ppm}$ of air-dry weight. $(*=$ contaminated by Nectria violacea,$-=$ not measured, because sample too small, $0=$ the level of the metal was almost as low as in the similarly treated 0-standard). The values are for individual slime molds.

\begin{tabular}{|c|c|c|c|c|c|c|c|c|c|c|c|c|c|c|}
\hline & \multirow[t]{2}{*}{ Sampling time } & \multirow[t]{2}{*}{ Substrate } & \multicolumn{6}{|c|}{ Metals in leaves of Vaccinium myrtillus } & \multicolumn{6}{|c|}{ Metals in Fuligo septica in toto } \\
\hline Area & & & $\mathrm{Al}$ & $\mathrm{Fe}$ & $\mathrm{Zn}$ & $\mathrm{Cu}$ & $\mathrm{Cd}$ & $\mathrm{Hg}$ & $\mathrm{Al}$ & $\mathrm{Fe}$ & $\mathrm{Zn}$ & $\mathrm{Cu}$ & $\mathrm{Cd}$ & $\mathrm{Hg}$ \\
\hline Kokemäki & 5.7 .1988 & pine stub & 150 & 102 & 14 & 5.3 & 0.020 & - & 160 & 300 & 10000 & 15 & 1.32 & - \\
\hline Kokemäki & 10.7 .1988 & pine stub & 97 & 26 & 25 & 6.3 & 0.092 & - & 200 & 180 & 14000 & 8.6 & 9.8 & 0.015 \\
\hline Kokemäki & 10.7 .1988 & pine stub & 140 & 63 & 43 & 8.5 & 0.052 & 0 & 190 & 330 & 11000 & 19 & 0.64 & 0.034 \\
\hline Köyliö & 24.7 .1988 & pine stub & 540 & 7.8 & 9.7 & 5.8 & 0.18 & - & 370 & 410 & 13000 & 17 & 1.0 & - \\
\hline Kokemäki & 26.7 .1988 & needle litter & 120 & 90 & 13 & 9.0 & 0.076 & 0.026 & 42 & 140 & 12000 & 6.2 & 1.5 & 0.023 \\
\hline Kokemăki & 26.7 .1988 & moss carpet & 120 & 90 & 13 & 9.0 & 0.076 & - & 67 & 240 & 15000 & 9.6 & 1.1 & - \\
\hline Kokemäki & 2.9.1988 & bog-spruce & 220 & 86 & 17 & 17 & 0.45 & 0.045 & 26 & 550 & 9400 & 11 & 1.8 & 0.037 \\
\hline Kokemăki & 2.9.1988 & needle litter* & 230 & 100 & 81 & 15 & 0.090 & - & 38 & 42 & 17000 & 23 & 3.2 & - \\
\hline Kokemäki & 2.9.1988 & moss carpet* & 200 & 46 & 49 & 4.3 & 0.038 & - & 9.3 & 22 & 4000 & 15 & 0.40 & - \\
\hline Kokemäki & 2.9.1988 & spruce stub* & 260 & 83 & 16 & 9.1 & 0.16 & - & 40 & 190 & 15000 & 12 & 4.0 & - \\
\hline Kokemáki & 2.9 .1988 & needle litter* & 360 & 84 & 160 & 9.4 & 0.066 & 0.063 & 55 & 220 & 16000 & 6.3 & 2.5 & 0.057 \\
\hline Espoo & 20.7.1988 & $\begin{array}{l}\text { spruce base } \\
\text { near the ground }\end{array}$ & 52 & 23 & 24 & 8.9 & 0.10 & - & 10 & 37 & 18000 & 5.1 & 3.4 & 0.013 \\
\hline Espoo & 7.8 .1988 & $\begin{array}{l}\text { spruce base } \\
\text { near the ground }\end{array}$ & 230 & 69 & 120 & 8.1 & 0.047 & - & 41 & 450 & 20000 & 0 & 0.53 & - \\
\hline Nurmijärv & 22.9.1988 & needle litter* & 340 & 120 & 79 & 7.2 & 0.14 & - & 170 & 720 & 14000 & 9.0 & 1.1 & - \\
\hline Nurmijärv & 22.9.1988 & spruce stub* & 310 & 110 & 79 & 7.8 & 0.15 & - & 19 & 33 & 4000 & 13 & 4.3 & - \\
\hline
\end{tabular}

\section{Results and discussion}

Slime molds are not infrequent in the field in Finland, but being scattered they are difficult to observe and they are often too small for metal analyses. It is not possible for an amateur field worker to obtain a large material during a single summer and the present material is merely intended to provide preliminary information for future work. The results are given in detail in Tables 2-4.

In order to illustrate the occurrence of metals in the different slime mold species, the metal levels in the individual slime molds were divided by the metal levels in the indicator plant $V$. myrtillus. The mean value and standard deviation of the ratios for each species were calculated. If the mean value was under 1 , the ratio was recalculated using the metal content of the slime mold as a divisor. This is a convenient way of describing the behavior of different metals in different slime mold species. Figs. 1-3 show that the levels of the common soil metals $\mathrm{Al}$ and $\mathrm{Fe}$ are higher in V. myrtillus, whereas all the other metals have higher contents in the slime molds. The levels of $\mathrm{Al}$ and Fe in F.septica are the only clear exception to this rule. $\mathrm{Zn}$ and $\mathrm{Cd}$ are accumulated by slime molds remarkably vigorously.

The trends described above can be attributed to the fact that $V$. myrtillus takes its nutrients from both humus and the mineral soil, whereas slime molds are considered to be confined to humus and decaying material.

The high levels of $\mathrm{Zn}$ in $F$. septica cannot be explained at present. $\mathrm{Zn}$ has not been observed to protect Physarum polycephalum against $\mathrm{Cd}$, though this is the case in Eschericia coli, mammals and insects (Chin \& Sina 1978, Elinder \& Piscator 1987, Mailman 1981, Pihlajamäki et al 1989, Rantataro et al. 1989, Reddy et al. 1987, Vogel et al. 1988, Yamoto et al. 1987). Zn possibly affords protection from some more dangerous factor by acting as a coenzyme or enzyme activator in detoxification systems (Migula \& Kedziorsky 1986). The mechanisms of the accumulation and toleration of zink are also obscure.

The high levels of $\mathrm{Cd}$ are also difficult to understand. In studies of the toxicity of $\mathrm{Cd}$ to $P$. polychephalum effects on the biochemistry of the nucleus, membrane potential and survival time have been noted (Chin et al. 1973, Chin et al. 1978a, b, Chin \& Sina 1978, Terayama et al. 1978). When do the toxic metals affect the slime molds in nature?

Though the number of samples was small the levels of $\mathrm{Fe}$ and $\mathrm{Zn}$ in F. septica proved to be statistically significantly higher in nature than in the museum samples $(\mathrm{Fe}, \mathrm{p}=0.05$ and $\mathrm{Zn}, \mathrm{p}=0.01)$.

Analyses of museum samples (Table 1) show that high metal levels existed in slime molds before the environment was subjected to the recent pollution load. 
Table 3. Scattered observations of the occurrence of metals in seven species of slime molds in different Finnish localities. The metal levels are given as $\mathrm{mg} / \mathrm{kg}$ dwt $=$ ppm of air-dry weight. $(-=$ not measured because sample too small, $0=$ the level of the metal was almost as low as in the similarly treated 0 -standard). The values are for individual slime molds, except for Amaurochaete atra in Kokemäki, where three slime molds of this species were found in an area approximately $5 \mathrm{~m}^{2}$ in size.

\begin{tabular}{|c|c|c|c|c|c|c|c|c|c|c|c|c|c|c|}
\hline \multirow[t]{2}{*}{ Area Sam } & \multirow[t]{2}{*}{ Sampling time } & \multirow[t]{2}{*}{$\begin{array}{l}\text { Slime mold } \\
\text { substrate }\end{array}$} & \multicolumn{5}{|c|}{$\begin{array}{l}\text { Metals in leaves of } \\
\text { Vaccinium myrtillus }\end{array}$} & \multicolumn{7}{|c|}{ Metals in slime mold } \\
\hline & & & $\mathrm{Al}$ & $\mathrm{Fe}$ & $\mathrm{Zn}$ & $\mathrm{Cu}$ & $\mathrm{Cd}$ & $\mathrm{Hg}$ & $\mathrm{Al}$ & $\mathrm{Fe}$ & $\mathrm{Zn}$ & $\mathrm{Cu}$ & $\mathrm{Cd}$ & $\mathrm{Hg}$ \\
\hline \multicolumn{15}{|c|}{ Lycogala epidenrum L. (Fries) } \\
\hline Espoo & 7.8.1988 & spruce stub & 14 & 7.8 & 8.3 & 4.0 & 0.020 & - & 15 & 25 & 76 & 7.2 & 2.0 & - \\
\hline Espoo & 14.8.1988 & spruce stub & 130 & 70 & 19 & 5.9 & 0.094 & - & 14 & 34 & 120 & 4.9 & 3.6 & - \\
\hline Espoo & 14.8.1988 & spruce stub & 250 & 120 & 28 & 9.5 & 0.13 & - & 0 & 22 & 130 & 0 & 12 & - \\
\hline Juupajoki & 8.9.1988 & birch trunk & 84 & 46 & 11 & 4.1 & 0.48 & - & 4.8 & 7.0 & 100 & 3.4 & 0.38 & - \\
\hline Juupajoki & 12.9.1988 & pine stub & 240 & 62 & 16 & 8.7 & 0.50 & - & 45 & 23 & 62 & 3.3 & 0.64 & - \\
\hline Juupajoki & 16.9 .1988 & pine stub & 200 & 63 & 16 & 5.6 & 0.025 & - & 17 & 25 & 160 & 3.5 & 0.48 & - \\
\hline Juupajoki & 17.9 .1988 & $\begin{array}{l}\text { trunk in } \\
\text { swamp }\end{array}$ & 300 & 52 & 21 & 8.1 & 0.037 & - & 6.1 & 19 & 68 & 17 & 1.1 & - \\
\hline \multicolumn{15}{|c|}{ Symphytocarpus flaccidus (Morgan) } \\
\hline \multirow[t]{5}{*}{ Pyhäranta } & 20.7 .1988 & spruce stub & 160 & 100 & 16 & 5.3 & 0.034 & 0.023 & & & & & & \\
\hline & & Aethalium A & & & & & & & 11 & 32 & 270 & 14 & 11 & 0.035 \\
\hline & & Aethalium B & & & & & & & 32 & 65 & 200 & 8.6 & 7.7 & 0.032 \\
\hline & & Plasmodium & & & & & & & 6.5 & 11 & 150 & 6.4 & 7.2 & 0.020 \\
\hline & & $\begin{array}{l}\text { Plasmodium } \\
\text { after } 3 \mathrm{~h}\end{array}$ & & & & & & & 11 & 20 & 170 & 8.3 & 9.7 & 0.10 \\
\hline Espoo & 14.8 .1988 & pine stub & 130 & 41 & 13 & 5.0 & 0.046 & - & 28 & 43 & 180 & 7.8 & 5.6 & - \\
\hline Juupajoki & 8.9 .1988 & birch trunk & 84 & 46 & 11 & 4.1 & 0.048 & - & 34 & 32 & 120 & 5.7 & 3.6 & - \\
\hline \multicolumn{15}{|c|}{ Tubifera ferruginosa (Batsch) } \\
\hline Kokemäki & i 2.9 .1988 & spruce stub & 240 & 82 & 15 & 10 & 0.12 & - & 44 & 57 & 210 & 26 & 1.2 & - \\
\hline Kokemäki & i 2.9 .1988 & moss carpet & 200 & 46 & 49 & 4.3 & 0.38 & - & 9.3 & 13 & 150 & 19 & 1.6 & - \\
\hline Kokemăki & i 2.9 .1988 & moss carpet & 120 & 77 & 12 & 8.4 & 0.38 & - & 99 & 96 & 570 & 19 & 4.6 & - \\
\hline \multicolumn{15}{|c|}{ Amaurochaete atra (Albert.\& Schweinitz) } \\
\hline \multicolumn{15}{|l|}{ Nummi- } \\
\hline Pusula & 15.7 .1988 & birch stub & 110 & 4.2 & 20 & 6.0 & 0.080 & - & 75 & 33 & 240 & 8.4 & 3.6 & - \\
\hline Kokemäki & i 26.7 .1988 & pine stub & 71 & 35 & 250 & 7.3 & 3.5 & 0.085 & 38 & 32 & 240 & 9.4 & 3.8 & 0.12 \\
\hline \multicolumn{15}{|c|}{ Ceratiomyxa fruticulosa (O.F. Müller) } \\
\hline Espoo & 7.8 .1988 & spruce stub & 120 & 47 & 28 & 4.5 & 0.036 & - & 16 & 36 & 150 & 14 & 0.94 & - \\
\hline \multicolumn{15}{|c|}{ Stemonitis sp. } \\
\hline Vantaa & 21.8 .1988 & spruce stub & 62 & 130 & 20 & 9.8 & 0.62 & - & 290 & 110 & 23 & 8.9 & 0.051 & - \\
\hline \multicolumn{15}{|l|}{ Plasmodia } \\
\hline Espoo & 7.8 .1988 & spruce stub & 230 & 69 & 120 & 8.1 & 0.047 & - & 12 & 31 & 96 & 12 & 1.0 & - \\
\hline Vantaa & 21.8 .1988 & spruce trunk & 290 & 110 & 23 & 8.9 & 0.51 & - & 64 & 63 & 210 & 23 & 0.93 & - \\
\hline
\end{tabular}

When the metal contents in the hypothallus and sporophore of $F$. septica were compared, hypothallus was found to contain more $\mathrm{Zn}$ (statistically significant, $\mathrm{p}=0.01$ ) than the spore bearing part. This raises the question whether $\mathrm{Zn}$ is necessary for the formation of the hypothallus or is secreted as a waste to the hypothallus in order to protect the sporophore and spores against damage by the metal.

The contents of $\mathrm{Fe}$ were also higher in the hypothallus the difference being statistically almost signifi- cant. The reason for this may be one of those suggested above.

When the Cd levels of the slime molds were compared with the Cd levels in lawn decomposing and mycorrhizal fungi (Kuusi et al. 1981) the slime molds, mostly collected from rural districts, were found to have higher $\mathrm{Cd}$ levels than the fungi collected from the rural districts, and approximately as high $\mathrm{Cd}$ contents as the fungi collected from urban areas. 
Table 4. Comparison between metal levels (ppm of air-dry weight) in hypothallus and sporophore in Fuligo septica individuals.

\begin{tabular}{|c|c|c|c|c|c|c|c|}
\hline & & $\mathrm{Al}$ & $\mathrm{Fe}$ & $\mathrm{Zn}$ & $\mathrm{Cu}$ & Cd & $\mathrm{Hg}$ \\
\hline \multirow[t]{3}{*}{ 10.7.1988 } & Kokemäki & & & & & & \\
\hline & Hypothallus & 26 & 480 & 28000 & 7.2 & 1.0 & - \\
\hline & Sporophore & 74 & 140 & 12000 & 8.8 & 11 & 0.015 \\
\hline \multirow[t]{3}{*}{10.7 .1988} & Kokemäki & & & & & & \\
\hline & Hypothallus & 70 & 570 & 18000 & 19 & 0.69 & - \\
\hline & Sporophore & 210 & 280 & 9700 & 19 & 0.63 & 0.034 \\
\hline \multirow[t]{3}{*}{ 26.7.1988 } & Kokemäki & & & & & & \\
\hline & Hypothallus & 190 & 480 & 24000 & 3.8 & 0.54 & - \\
\hline & Sporophore & 36 & 120 & 11000 & 6.4 & 1.5 & 0.023 \\
\hline \multirow[t]{3}{*}{26.7 .1988} & Kokemäki & & & & & & \\
\hline & Hypothallus & 130 & 250 & 27000 & 11 & 0.58 & - \\
\hline & Sporophore & 50 & 240 & 12000 & 9.3 & 1.2 & - \\
\hline \multirow{2}{*}{20.7 .1988} & $\begin{array}{l}\text { Espoo } \\
\text { Hypothallus }\end{array}$ & 39 & 120 & 31000 & 4.7 & & - \\
\hline & Sporophore & 1.9 & 14 & 14000 & 5.3 & 1.1 & 0.013 \\
\hline
\end{tabular}

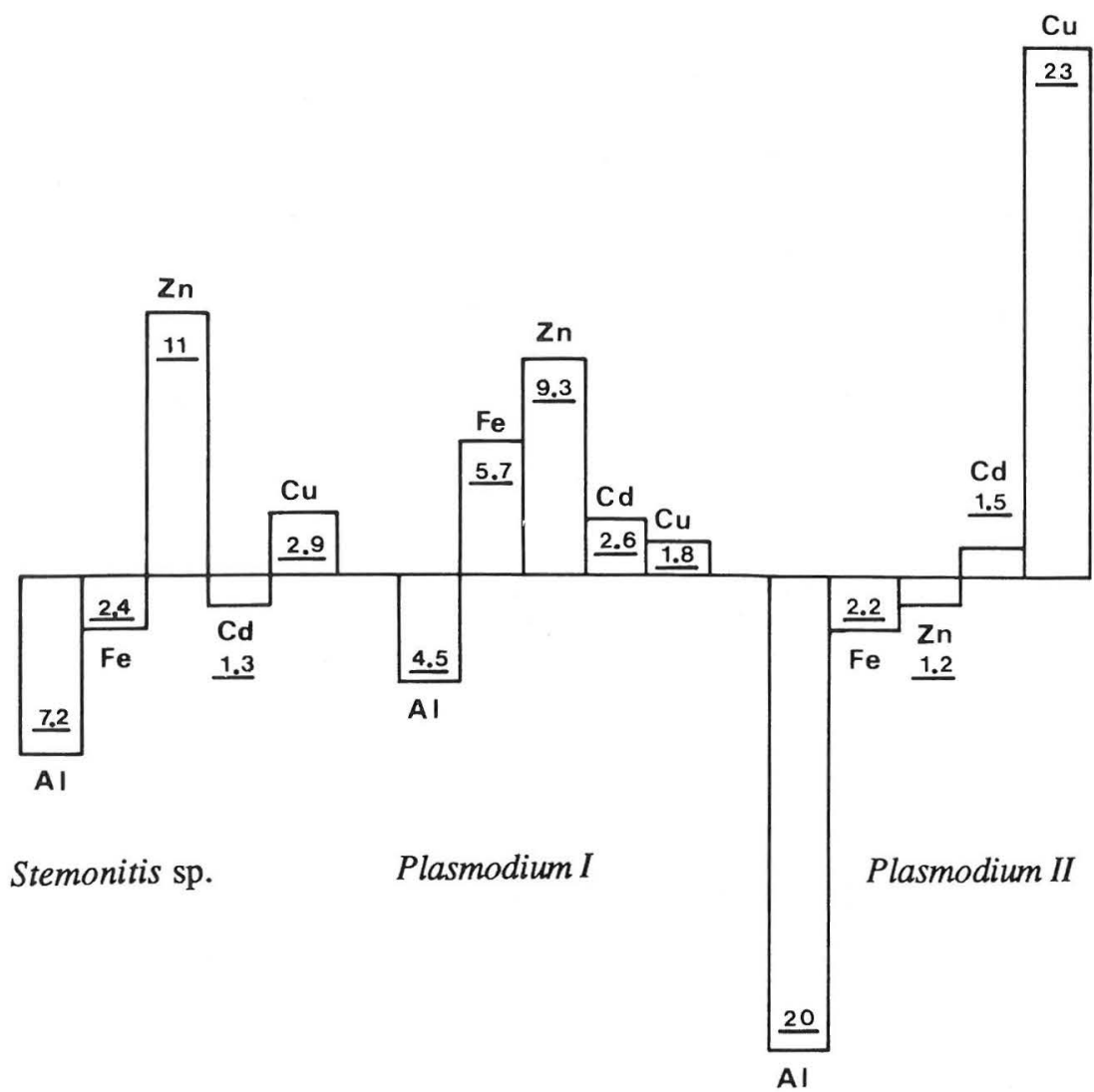

Fig. 1. See the next page for the explanation text. 


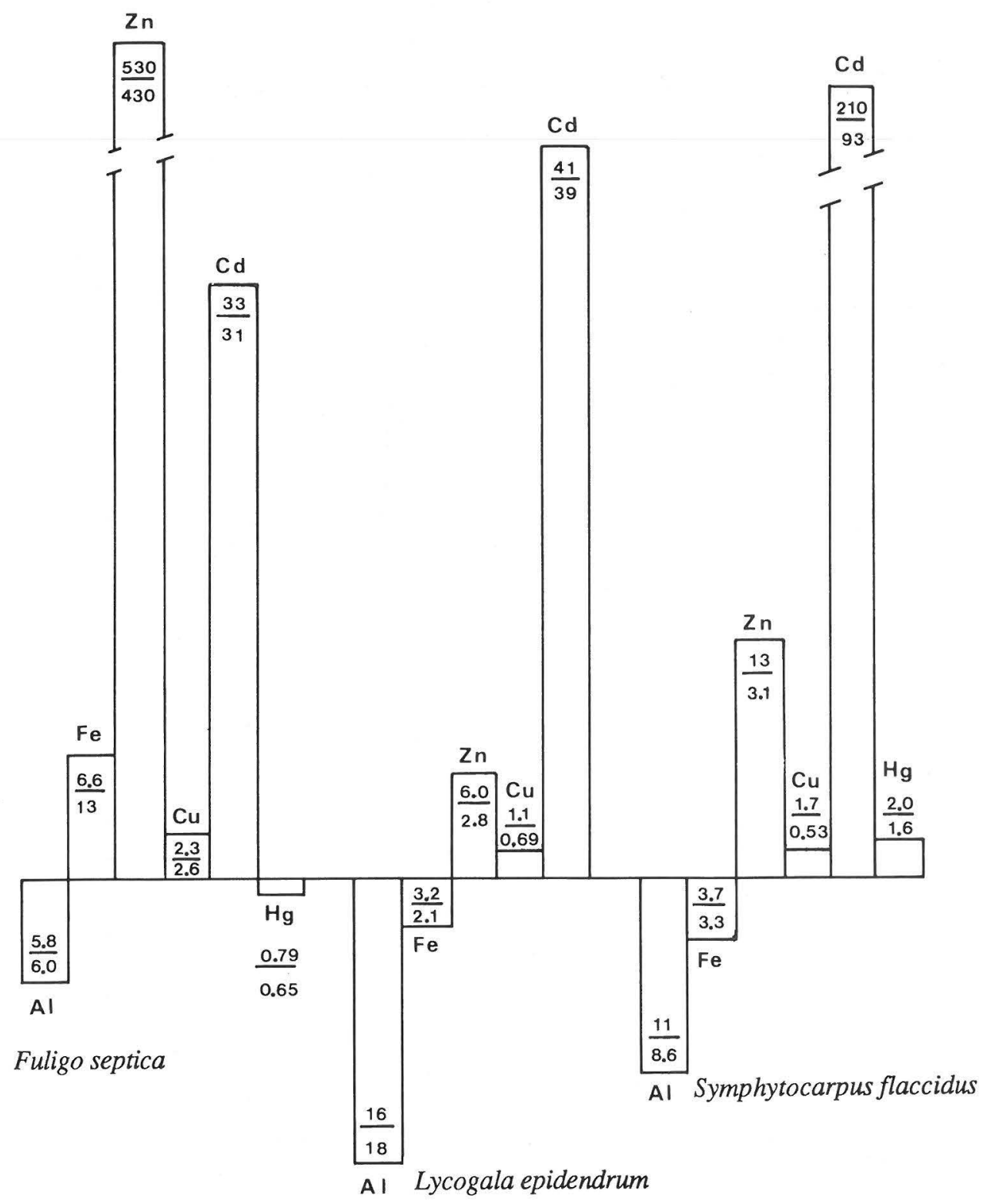

Figs. 1-3. Metal contents in some Myxomycetes compared with levels in Vaccinium myrtillus leaves. The horizontal line represents the metal content in the reference plant, Vaccinium myrtillus. Above this line, the columns and numbers show the ratio of the metal content of the Myxomycete to the metal content of $V$. myrtillus. Below this line, the columns and numbers show the ratio of the metal content of $V$. myrtillus to the metal content of Myxomycete. The number underlined is the mean value of the ratio and the number under it is the mean deviation.

Acknowledgements. We thank Marja Härkönen, Ph.D., for identifying the slime molds and giving valuable advice, Risto Willamo, M.Sc., Dept. of Environmental Conservation for help in statistical tests, Mr Esa Tulisalo for advice on the labo- ratory work and Mr Tapio Haapala for assistance in preparation of the diagrams. This research was supported financially by the Finnish Ministry of the Environment, as a part of the Finnish Acidification Research Project (HAPRO). 


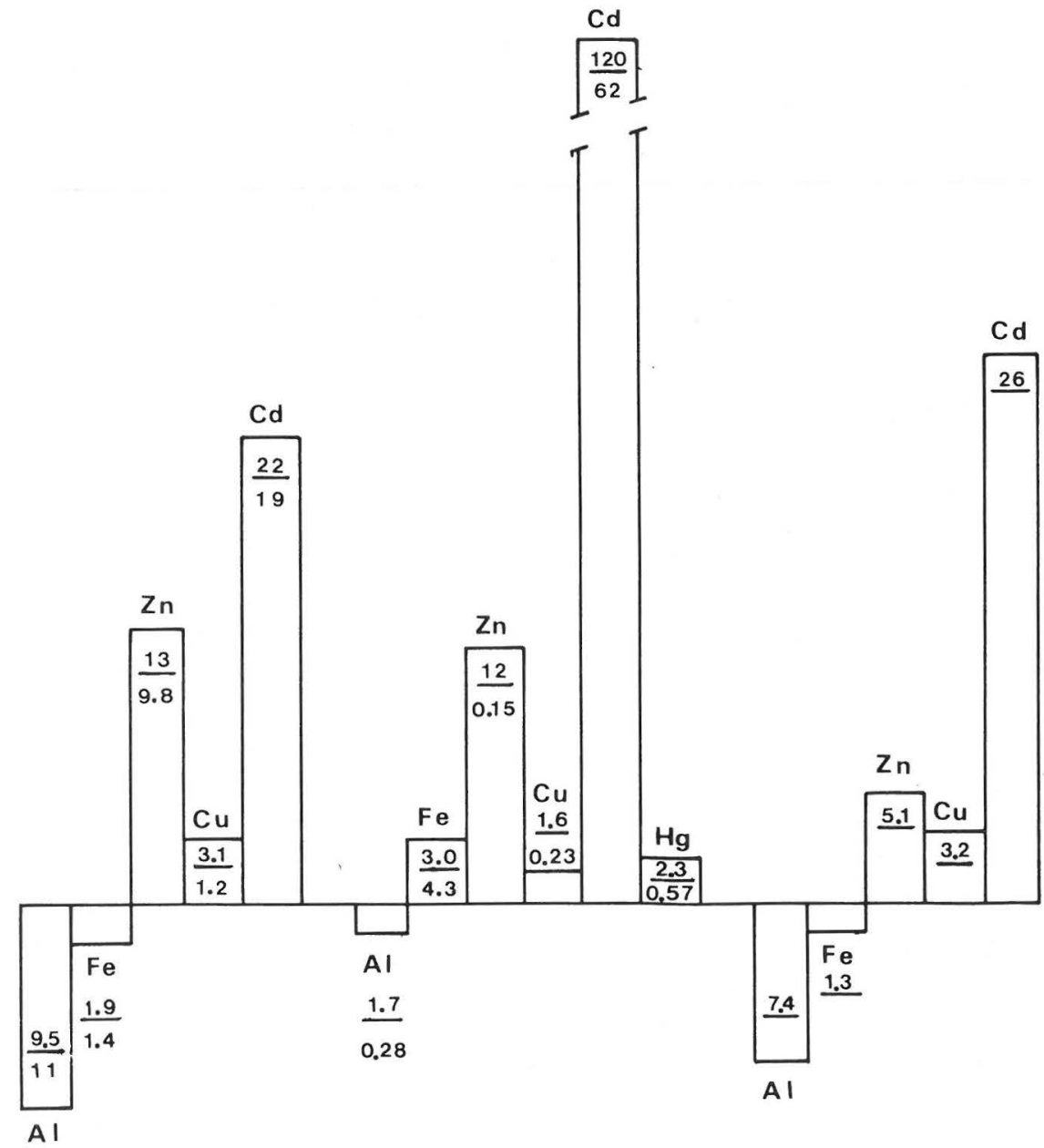

Tubifera ferruginosa Amaurochaete atra Ceratiomyxa fruticulosa

Figs. 1-3. See left for the explanation text.

\section{References}

Andersen, C. 1978: Cadmium, lead and calcium content, number and biomass, in earthworms (Lumbricidae) from sewage sludge treated soil. - Pedobiologia 19:309-319.

Arstila, A.U., Hänninen, K. \& Makkonen, S. 1986: Harjavallan seudun raskasmetallipäästöjen seuraaminen kaneilla bioakkumulaatiomallia hyväksi käyttäen (in Finnish). - Ympäristö ja Terveys 5/1986, 280-285.

Bengtson, G. \& Rundgren, S. 1984: Ground living invertebrates in metal polluted forest soils. - Ambio 13(1): 29-33.

Beyer, N. \& Anderson, A. 1985: Toxicity to woodlice of zinc and lead oxides added to soil litter. - Ambio 14(3): 173-174.
Beyer, W.N., Chaney, R.L. \& Mulhern, B.N. 1987: Heavy metal concentrations in earthworms from soil amended with sewage sludge. - Journal of Environmental Quality 11(3): 381-385.

Beyer, W.N., Pattee, O.H., Sileo, L., Hoffman, D.J \& Mulhern, B.N. 1985: Metal contamination in wildlife living near two zinc smelters. - Environmental Pollution (Series A) 38:63-86.

Chin, B., Lesowitz, G. \& Bernstein, I.A. 1973: Accommodation to low levels of environmental stressors: Protection against cadmium-Induced mitotic delay in Physarum polycephalum. - Abstracts of the Annual Meeting of the American Society for Microbiology 1973 
73rd annual meeting Miami Beach, Flo 6-11 May 1973 $38 \mathrm{pp}$.

- 1978: Cellular model for studying accommodation to environmental stressors: Protection and potentiation by cadmium and other metals. - Environmental Research 16: $432-442$.

Chin, B., Lesowitz, G.S., Bernstein, I.A. \& Dinman, B.D. 1978: A cellular model for studying accommodation to environmental stressors: A protective response to subtoxic exposure to cadmium. - Environmental Research 16:423-431.

Chin, B. \& Sina, J.F. 1978: Cellular bases of cadmium toxicity in Physarum. - Trace substances in environmental health, proceedings 12:214-219.

Cray, W.D. \& Alexopoulos, C.J. 1968: The biology of Myxomycetes. - The Ronald press Company, New York $249 \mathrm{pp}$.

Elinde, C-G. \& Piscator, M. 1987: Cadmium and zinc relationships. - Environm. Health Perspectives 26:129 132.

Heliövaara, K., Väisänen, R., Braunschweiler, H. \& Lodenius, M. 1987: Heavy metal levels in two biennal pine insects with sap-sucking and gall-forming lifestyles. - Environmental Pollution 48:13-23.

Hynninen, V. 1986: Monitoring of airborne metal pollution with moss bags near an industrial source at Harjavalta, southwest Finland. - Ann. Bot. Fennici 23:83-90.

Kanerva, T., Sarin, O. \& Nuorteva, P. 1988: Aluminium, iron, zinc, cadmium and mercury in some indicator plants growing in south Finnish forest areas with different degrees of damage. - Ann. Bot. Fennici 25:275-279.

Koski, E., Venäläinen, M. \& Nuorteva, P. 1988: The influence of forest type, topographic location and season on the levels of $\mathrm{Al}, \mathrm{Fe}, \mathrm{Zn}, \mathrm{Cd}$ and $\mathrm{Hg}$ in some plants in southern Finland. - Ann. Bot. Fennici 25:365-370.

Kuokkanen, E. 1986: Harjavallan yhdyskuntailman mittaustulokset 1.6.1978-31.12.1985 (in Finnish). — Ymparistö ja Terveys, 5/1986, 286-291.

Kuusi, T., Laaksovirta, K., Liukkonen-Lilja, H., Lodenius, M. \& Piepponen, S. 1981: Lead, cadmium and mercury contents of fungi in the Helsinki area and in unpolluted control areas. - Z Lebensm. Unters. Forsch, 1981: 173:261-267.

Laaksovirta, K. \& Silvola, J. 1975: Effects of air pollution by copper, sulphuric acid and fertilizer factories on plants at Harjavalta, W. Finland. - Ann. Bot. Fennici $12: 81-88$.

Mailman, R.B. 1981: Heavy Metals - Guthrie, F.E. \& Perry, J.J. (eds.), Introduction to environmental toxicology, Oxford, 484 pp.

Migula P. \& Kedziorski, A. 1986: The effect of the dietary zinc and associated pyrethroid resistance in the Colorado potato beetle (Leptinotarsa decemlineata Say) -
Acta Biol. Silesiana 5 (22): 7-20.

Pihlajamäki, J., Väänänen, V-M., Koskinen, P. \& Nuorteva P. 1989: Metal levels in Laothoe populi and Sphinx pinastri (Lepidoptera, Sphingidae) in Finland Ann. Entomol. Fenn. 55:17-21.

Pokarzhevskij, A.D., Mondspiegel, K. \& Zhulidov, A.V. 1978: The importance of soil Saprophages in the cycle of microelements in forest Steppe Oak stands. Proceedings of the 4th International Conference Bioindicatores Deteriorisationis Regionis 28th June-2nd July 1982, Edited by J. Pankert, V. Ruzicka, J. Bohak, Ceske Budejovice 1986 p. 379-385.

Pokarzhevskij, A.D., Zhulidov, A,V. \& Mikhaltzova, Z.A. 1982: Levels of microelement concentrations in soil animals from reserve territories of USSR. - Proceedings of the 4th International Conference Bioindicatores Deteriorisationis Regionis 28th June-2nd July 1982, Edited by J. Pankert, V. Ruzicka, J. Bohak, Ceske Budejovice 1986 p. 202-203.

Rantataro, M., Laine, J., Koskinen, P. \& Nuorteva, P. 1989: Metal contents in the Scots pine feeding moths Dendroli mus pini L. (Lep., Lasiocampidae), Bubalu piniarius L. (Lep., Geometridae) - Proc. V Internat. Conf. Bioindicatores Deteriorisationis Regionis, Cesce Budejovice 1988 (in press).

Reddy, C.S., Mohammad, F.K., Ganjam, V.K., Martino, V.A. \& Brown E.M. 1987: Mobilization of tissue cadmium in mice and calves and reversal of cadmium induced tissue damage in calves by zinc. - Bull. Environm. Contam. Toxicol. 39:350-357.

Särkelä, M. \& Nuorteva, P. 1987: Levels of aluminium, iron, zinc, cadmium and mercury in some indicator plants growing in unpolluted Finnish Lapland. - Ann. Bot. Fennici 24:301-305.

Sippola, J. \& Erviö, R. 1986: Raskasmetallit maaperässä ja viljelyskasveissa Harjavallan tehtaiden ympäristössä (in Finnish). — Ympäristö ja Terveys, 5/1986, p. 270- 275.

Terayama, K., Honma, H. \& Kawarabayashi, T. 1978: Toxicity of heavy metals and insecticides on slime mold Physarum polycephalum. - The Journal of Toxicological Sciences, 3:293-304.

Tyler, G. \& Westman, L. 1979: Effecter av tungmetallförorening på nedbrytningsprocesser i skogsmark VI Metaller och svafvelsyra. - Statens Naturvårdsverk, PM 1203 Solna p.4-33.

Vogel, W.R., Hopp, H., \& Führer, E. 1988: Stoffwechsel, Entwicklung und Fortpflanzung von Insekten und Antagonisten unter Schwermetalleinfluss - FIW-Symposium 1988: Waldsterben in Österreich — Theorien, Tendenzen, Therapien, Wien 1988, p. 228-246.

Yamoto, I., Itoh, M. \& Tsukada S. 1987: Determination of cadmium, copper, zinc and lead in human renal calculi in both cadmium polluted and non-polluted areas. — Bull. Environm. Toxicol. 39:343-349. 